\title{
Three-Dimensional Simulation of The Water Flow in Cilacap's Water, Indonesia
}

\author{
N. O. E. Froditus, D. G. Pratomo, and C. B. Pribadi
}

\begin{abstract}
Modelling of the water flow distribution in Cilacap's water, Indonesia is challenged by geographically properties. This area is a strait adjacent to Indian Ocean with a strong current flow characteristic. A three-dimensional model has been developed to understand the pattern of the flow and the sediment distribution in this waters. The parameters used in modeling includes hydro-oceanography, such as tidal, river discharge, bathymetry and sediment. River discharge that used came from Donan and Yasa River. In this research current and sediments model will be makes using numerical simulation with hydrodynamics equations. Based on the hydrodynamic simulation, at the spring tide period, the average and the maximum current magnitude are $0.6 \mathrm{~m} / \mathrm{s}$ and $0.8 \mathrm{~m} / \mathrm{s}$ respectively. But at this time the cumulative erosion/sedimentation is not too large. During the neap tide, the average current magnitude is 0.2 $\mathrm{m} / \mathrm{s}$ and the sediment is moving significant at river. So in this time experience a great erosion/sedimentation. The dominant type of sediment in this waters is a type of sand. The sediment deposition in this area affects the shipping lane, particularly in the vicinity of the jetty.
\end{abstract}

Keywords-

\section{INTRODUCTION}

The Geographically of Cilacap Regency located on coastal and this located directly facing with Indian Ocean, right at Penyu Bay and Nusakambangan Island stretching East-West. This is affect the waters of Cilacap have ideal ocean port and very busy with ship traffic activity [1]. One of important objects in operational activities in cruise activity, because jetty is building of port for ship docked and mooring.

For example, the Jetty of Wijayapura Port (Cilacap Regency) and Sodong Port (Nusakmbangan Island), is commonly used to mobilization criminals to Nusakambangan Jail by Departement of Judgement. Both of them are are important to accessibility between Nusakambangan Island and Cilacap Regency to cross Cilacap Strait [2]. The location of jetty in the strait and estuary of the river give effects prone to influence of sedimentation, which it is feared giving effect to activities mooring ship. This is coused by movement of current and sediment fraction characteristics that exist in these waters. Given the performance of port is very dependent on the depth of fairway and port basin [3]. One step to overcome superficiality is done by process of dredging sediments that settles. Therefore, so that the process of dredging running effectively, need knowledge about phenomenon of

N. O. E. Froditus, D. G. Pratomo, and C. B. Pribadi are with Department of Geomatics Engineering, Institut Teknologi Sepuluh Nopember, Surabaya, 60111, Indonesia. E-mail: cherie_b@geodesy.its.ac.id. hydrodynamics and sediment transport with numerical model simulations.

In this study, approach was conducted to understand pattern of current and sediment through application using numerical simulation with hydrodynamics equations. Study of numerical modelling in this research is expected to be done using Delft3D software, so current and sediment distribution pattern can be found periodically and continuous. The hope can analyse impact of given against Jetty of Wijayapura Port and Sodong Port.

\section{Methodology}

\section{A. Research Area}

The location of this research is waters of Cilacap, Cilacap Regency, Central Java, which is focused on water of Cilacap Strait. Geographically location in this research at coordinates $7^{\circ} 43^{\prime} 30^{\prime \prime} \mathrm{S}$ and $108^{\circ} 59^{\prime} 18^{\prime \prime} \mathrm{E}$ to $7^{\circ} 45^{\prime} 54^{\prime \prime} \mathrm{S}$ and $109^{\circ} 3^{\prime} 42^{\prime \prime}$ E, shown in Figure 1.

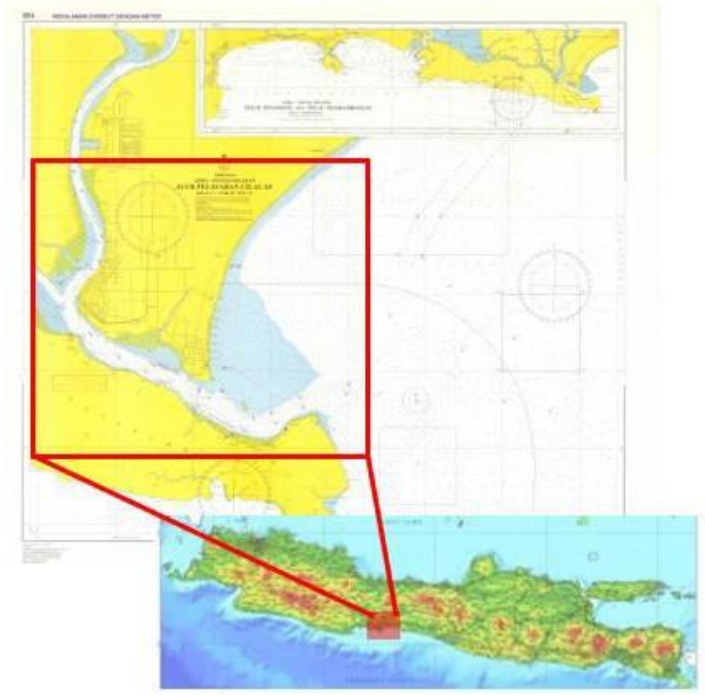

Figure 1. The Location of Research Area, Cilacap-Nusakambangan Chart Map (Pushidrosal).

So, UTM projection system used is zone 49S, with units of measure used to stated coordinates $(\mathrm{x}, \mathrm{y})$, depth $(\mathrm{z})$, and other aspects are meters (m).

\section{B. Tools and Data Acquisition}

In this research used spatial and hydro-oceangraphy data. The spatial data include Chart Map (CilacapNusakambangan) 2006 and RBI Map CilacapNusakambangan 1999. While hydro-oceanography data include: bathymetry, tide elevation data, current from results 
of ADCP, speed and direction of wind, sediment and river discharge. In order processing and analysis this research utilizes software:

a. Delft3D as software modelling.

b. ArcGIS 10.3 for process digitation on screen.

c. Matlab R2014a, as maker's script to help processing data.

d. File format conversion software.

\section{Methods}

1) Digitation on Screen

Early stages of processing data in this study are to take rectification and digitation RBI map and Chart map, using ArcGIS software. Process digitation to RBI map will be results coastline data has vertical datum reference on Mean Sea Level (MSL). While, from process digitation Chart map will be results spot depth. All of them have a data format in *.shp, so needs to be converted into a file format as needed for the next process.

2) Created Model Domain (Mesh)

Beginning with defining the borders of model (close boundaries) that is represented by coastline and condition of jetty, so land area and waters can be differentiated. The next process is building mesh processing, by using RGFGRID module. In this study grid made in structured grid type, with square shape model. The grid model is divided into several sections, shown in Table 1.

TABLE 1.

A GRID SIZE IN THE SIMULATION MODEL

\begin{tabular}{rlc}
\hline \hline No & \multicolumn{1}{c}{ Name } & Size (m) \\
\hline 1 & Grid Laut 1 & $120 \times 120$ \\
2 & Grid Laut 2 & $60 \times 60$ \\
3 & Grid Muara \& Sungai & $30 \times 30$ \\
4 & Grid Selat & $10 \times 10$ \\
\hline \hline
\end{tabular}

While, main of building mesh processing is giving values of depth at each grid cell, by means of interpolation in QUICKIN module. The interpolation method used triangular method, with information of depth from bathymetry dan spot depth data.

\section{3) Tide Data Processing}

Tidal observations data used field observation that 29 days, with interval observation is 1 hour. Next, calculation of amplitude value and 9 constituent tidal, used to find out value of vertical datum MSL, as well type of tidal with Formzahl formulas bellow:

$$
F=\frac{A K 1+A O 1}{A M 2+A S 2}
$$

Wherever $\mathrm{F}$ is number of Formzahl, while AKI, AO1, $\mathrm{AM} 2$, and AS2 are amplitude value of each constituen from $\mathrm{K} 1, \mathrm{O} 1, \mathrm{M} 2$, and S2. With this amplitude has a unit of meters. Input of primary parameters for power current generator is tide elevation data with datum MSL equal to zero, then it is necessary datum shift process. This process will be done by subtracting any tidal observation data against value of MSL on previous calculations.

\section{4) Current and Sediment Modeling}

The simulation model is run for 29 days from July, 12 up to August 19, 2017 with time frame that is divided into 4.5 days (warming up), 0.5 days (spin up), and 24 days (simulation). In this research used time step 0.05 seconds, it has considered terms of stabitity of CFL (Courant Friedich Lewy).

Modelling in this research besides to definition of close boundaries, also do a defining open boundaries. Based on power current generator, open boundaries are divided into 2 types. The first type is an open boundaries with power current generator from water lavel (tide) in 29 days and the second open boundaries is river discharge (Donan River and Yasa River).

Besides to above parameters, used wind parameters and also sediment fraction. Wind data consists of daily speed and direction wind obtained from BMKG. While, based on field data and 5 results of laboratory sediment, it is known that type of sediments at waters of Cilacap is sand, which belongs into non-cohesive sediment. In this model, the assumption sediment fraction has a specific density of 2659 $\mathrm{kg} / \mathrm{m}^{3}$. And value of dry density on $1600 \mathrm{~kg} / \mathrm{m}^{3}$, with a thickness of sedimentary based on 0.5 meters. Details of set up modelling as in Table 2.

TABLE 2.

\begin{tabular}{lc} 
SET UP OF CURRENT AND SEDIMENT MODELING PARAMETER \\
\hline \hline \multicolumn{1}{c}{ Description } & Value \\
\hline Coriolis & -7 degree \\
Number of layer & 1 layer \\
Processes & Constituents : Sediment \\
& Physical : Wind \\
Initial conditions & Uniform values \\
Initial water level & 0 meters \\
Boundary & Water level (tide) and \\
& river discharge \\
Morphology & Update depth \\
Numerical parameters & Center of grid \\
Roughness & Chezy \\
Interpolation type wind & Linear \\
Wind drag coefficients & Default \\
Initial concentration & 0 kg/m ${ }^{3}$ \\
sediments & \\
Sediment & 5 sample sediment sand \\
\hline \hline
\end{tabular}

\section{5) Model Data Validation}

The results of current model simulation, it is need to be validation process to test quality of data. This process is done against tidal and current data from acquisition and results of modelling. The calculation of statistics to be used obtained by calculating values of MAE (Mean Absolute Error) to know value and size of error rate of absolute model results deviate from observation data, with following formula [2]:

$$
M A E=\frac{1}{n} \sum_{j=1}^{n}\left|y_{j}-\hat{\mathrm{y}}_{j}\right|
$$

Moreover in this study used statistic tests is correlation coefficient calculation (R), this statistic test used for measure (strong, weak, or there is no) relationships between variabels (model and observation) [4]. 
The $3^{\text {rd }}$ Geomatics International Conference 2018 July $12^{\text {th }} 2018$, Institut Teknologi Sepuluh Nopember, Surabaya, Indonesia

\section{RESULT AND DISCUSSION}

\section{A. Model Domain (Mesh)}

One of important data in the contruction of mesh is a grid, created to represent area studies. In this research, area examined are an area of sea and river, so grid model made smaller, while in the river area. Figure 2 is a grid model in this research.

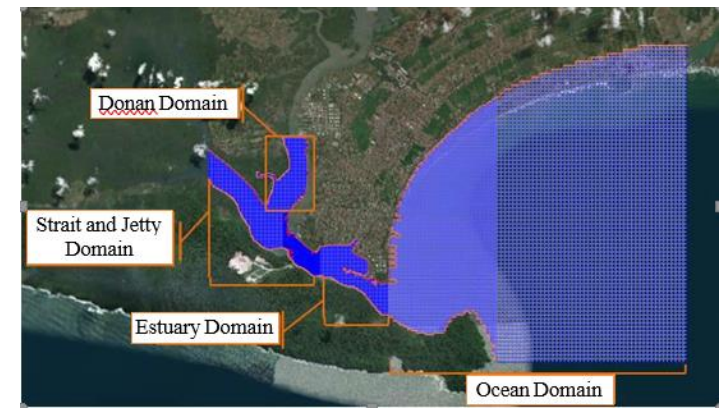

Figure 2. Grids Model.

So, the results from process of interpolation method with triangular interpolation on all grid model. From this process will be result and can be referred to as Mesh, which is given information about depth and model area. Shown in Figure 3.

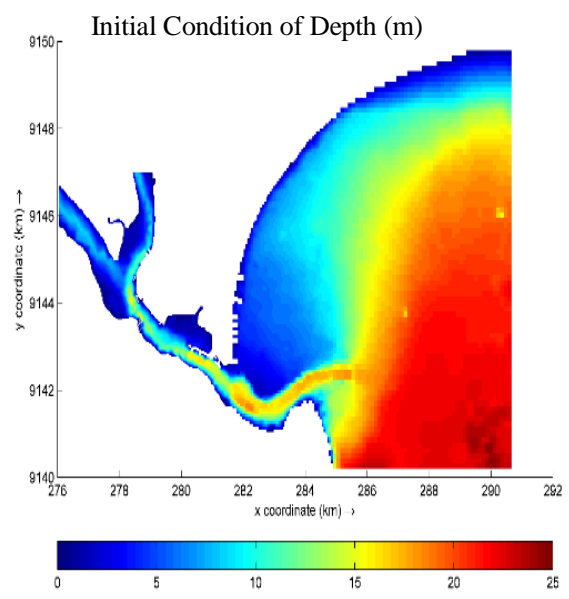

Figure 3. Domain Model (Mesh).

The information of waters depth indicated by contour of color gradation, with value of depth from 0 up to 25 meters. The deepest area in the sea, with a depth value of 20 up to 25 meters indicated by red color. While in the area of Jetty, depth value ranges between 2 up to 10 meters with color gradations of blue.

\section{B. Tide}

Tidal observation data is direct observation in the field at location of tidal station (tide palm), this located in Cilacap Strait with coordinates location is 7044'26" S and 108059'57" E. This observation data, used to get value of mean sea level (S0) and amplitude (A) as well phase $\left(\mathrm{g}^{\circ}\right)$ of 9 constituent harmonics Cilacap's Waters. These value are used to obtain value of reference high, using least square method. Shown in Tabel 3.
TABLE 3.

THE VALUE OF REFERENCE DEPTH

\begin{tabular}{cc}
\hline \hline Reference Depth & Depth $(\mathbf{m})$ \\
\hline MSL & 1.860 \\
LWL & 1.082 \\
HWL & 2.638 \\
\hline \hline
\end{tabular}

Depth reference value in Table 3 are used to do datum shift process. So, will be obtained tidal observation data with MSL depth reference. Moreover, with calculation using Formzahl equation, resulting value from number of Formzahl $(\mathrm{F})$ is equal to 0.356 . This means that type of tidal from Cilacap's Waters has type mixed semidiurnal tide. And then, in one day it will happen two times flood and ebb tide, with different height and periods.

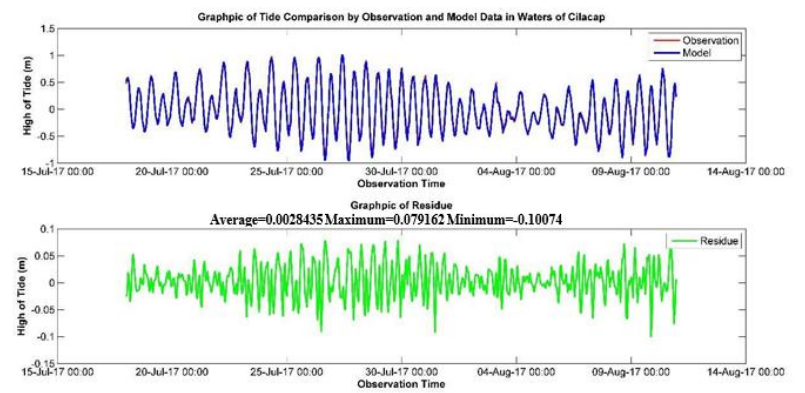

Figure 4. Graphic of Tide Comparison by Observation and Model Data in Waters of Cilacap.

In Figure 4 shows a comparison chart of tide data observations with models data. Data modeling starts from July 17 up to August 09, 2017 that obtain value of Mean Absolute Error (MAE) of 0.024 meters. This indicates that value of MAE obtained relative small, with error rate belongs to small classification [5]. Here is the calculation of

$$
\text { MAE: } M A E=\frac{1}{n} \sum_{j=1}^{n}\left|y_{j}-\hat{y}_{j}\right|=0.024 \text { meters }
$$

On the other hand, from the results of both of the data, correlation coefficient reaches 0.998 , this shows that the two variables are positively correlated and has a relation very high. A both correlation data shown in Figure 5.

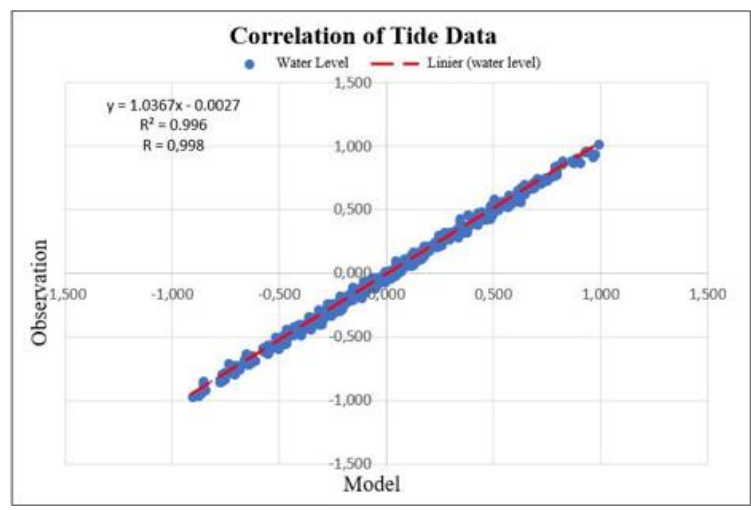

Figure 5. Correlation of Observation Tide and Model Tide Data.

Both of two statistic tests can be inferred that the algorithms of processing data goes well. Then, the current and sediment model can be used for the next process. 
The $3^{\text {rd }}$ Geomatics International Conference 2018

July $12^{\text {th }} 2018$, Institut Teknologi Sepuluh Nopember, Surabaya, Indonesia

\section{Current Modeling}

The resulting current pattern is pattern of currents that consists of speed value and direction of motion of current. The velocity of current is indicated by appropriate classification in the scale bar gradation. While, vectors represent motion variations of current direction.

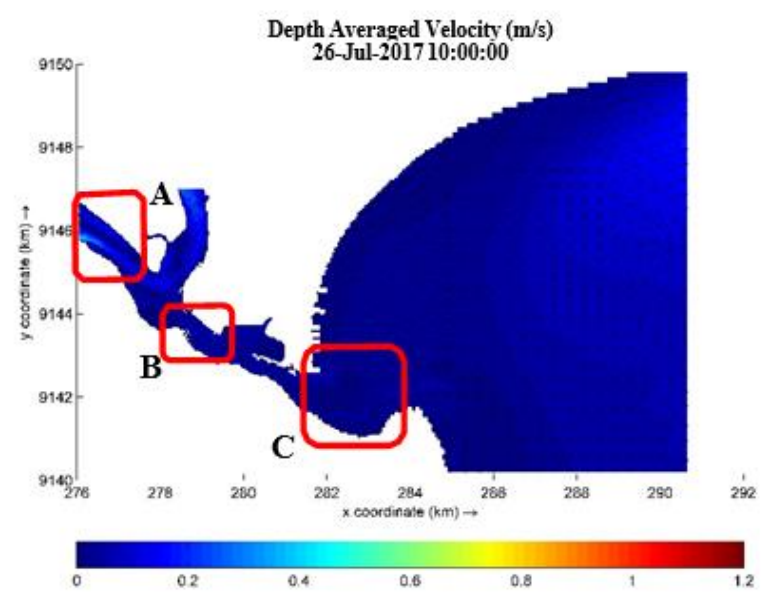

Figure 6. Pattern of Current Cilacap's Waters at Flood Spring Tide.

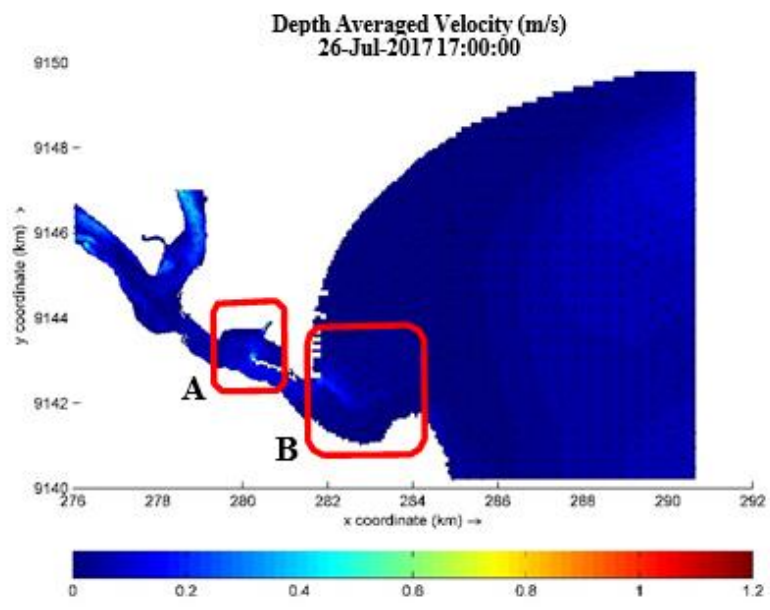

Figure 7. Patterns of Current Cilacap's Waters at Ebb Spring Tide.

The pattern of currents in spring period on Figure 6 such differences $e b b$ and flood conditions. In Figure 6a, demonstrates a pattern of currents on flood of spring tide conditions that occurred on July 26, 2017 at 10.00 AM on timestep 1385. The velocity of current in this condition ranged from 0 up to $0.6 \mathrm{~m} / \mathrm{s}$, with maximum velocity was in Cilacap Strait as designated by area A in Figure 6. Current vector formed at this condition indicates that current move from the sea to coastal area of Penyu Bay and moving towards the sea or towards to East in the area of Cilacap Strait. So, separating the direction of current on the location $\mathrm{C}$ in Figure 6. This is due, in this location is meeting point from two current with a different current power generator. The two current power generator are current tidal and river discharge, which met at Strait of Cilacap.

A dock shape that is jetty type, on site B, causing the current movements in Cilacap Strait is hindered by Jetty. So, the dominant current direction heads East on this condition, but there is a direction vector that back towards to West. The current velocity between 0.1 up to $0.3 \mathrm{~m} / \mathrm{s}$.

And then on Figure $6 \mathrm{~b}$, shown current pattern at ebb spring tide conditions that occurred on July 26, 2017 at 17.00 PM on timestep to 1413. The pattern of currents on these conditions experience increased current velocity. Current velocity range 0 up to $0.8 \mathrm{~m} / \mathrm{s}$ and the largest current at location A. Current in this location that comes from river discharge Yasa. What make s current pattern in ebb spring tide different is the current's direction. It can be seen that the direction is opposite from that of current in flood spring tide. Other than that, there are interesting phenomenon on site B. The current's direction vector, turns north towards to Jetty on coastal areas Penyu Bay. Morphological conditions mainland of Nusakambangan Island juts out to North, close the mount of estuary is partly cause of these phenomenon.

Afterwards, will be discussed about pattern of currents that occur neap period. In this period, the value of current velocity is relatively much smaller than in the spring period. August 5, 2017 at $01 \mathrm{AM}$ is the time which happens to flood neap tide. While, the ebb neap tide condition occurred at 19.00 PM.

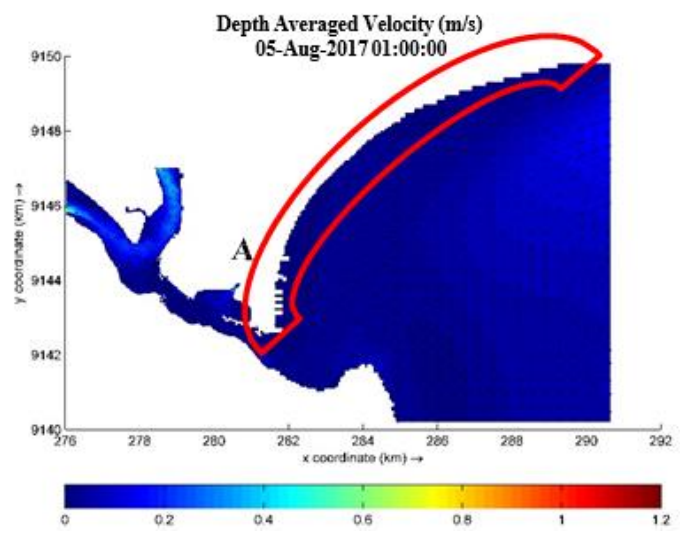

Figure 8. Patterns of Current Cilacap's Waters at Flood Neap Tide.

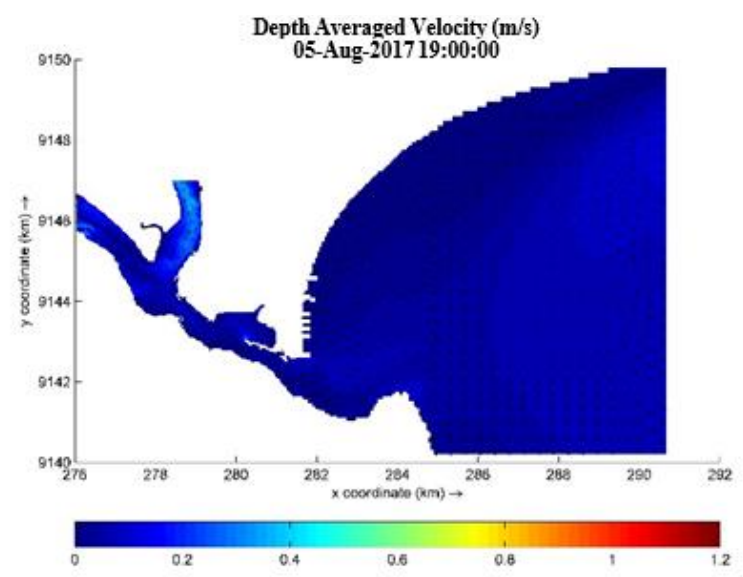

Figure 9. Patterns of Current Cilacap's Waters at Ebb Neap Tide. 
In Figure 8, shows a pattern of currrents on condition of flood neap tide, with maximum current velocity of $0.5 \mathrm{~m} / \mathrm{s}$. If seen current's direction on the simulation model, indicated on location of A. at these location occur longshore current or current parallel to coast, moving along coast Penyu Bay. Movement of current direction in the region are moving parallel with coast toward of South.

Then, on the Figure 9 shows pattern of currents on ebb neap tide conditions. Compared to velocity of current in the flood neap tide condition, current velocity in this condition to experience decline. Maximum velocity on these conditions only achieved $0.3 \mathrm{~m} / \mathrm{s}$, but with variation of velocity spreading vicinity at waters of Cilacap. Longshore current phenomenon also occurs in this condition, with the direction of current are moving parallel with coast toward of South. These phenomenon on Cilacap's water occurs due to phenomenon of wave break, that will form a new current with large specific angle that parallel with coast.

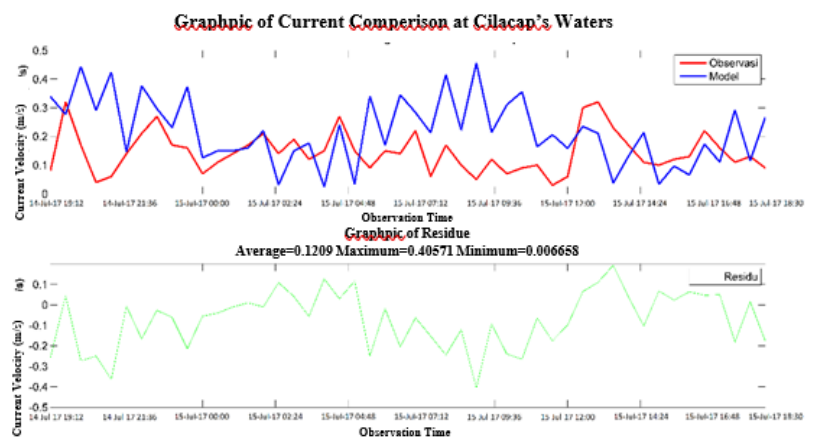

Figure 10. Graphics of Current Comparison of Observation and Model Data.

Figure 10 shows the comparison chart of observation current velocity and model current velocity, including residue. The validation process on both current data are sample data from same location. The location at coordinates $7^{0} 44^{\prime} 38,22^{\prime \prime} \mathrm{S}$ and $108059^{\prime} 57,37^{\prime \prime}$ E. Trough calculation of MAE, obtained value of $0.121 \mathrm{~m} / \mathrm{s}$ which means it has a fairly small error rate. But by looking at value of correlation coefficient, the both current data has no relation. Because in the field conditions, there are many factors that effect movement of current (in addition to tides, river discharge, etc.). These factors are salinity, temperature, sound velocity, etc.

\section{Sedimen Modeling}

Analysis of sediment distribution on this research will be analysed as well on two period that is spring period and neap period. Reviewed overall area of model in two period, the condition of erosion/sedimentation occur estuaries area, and Cilacap Strait including vicinity the jetty. On other hand if seen from spring and neap period, seen that area experience wide differences and value of erosion/sedimentation.

Analysis will be done at condition of cumulative erosi/sedimentation at Cilacap's waters. The cumulative erosion/sedimentation will be shown into image that will give erosion/sedimentation thickness information. This information presented into colour gradation. The value of negative (-) and positive (+) respectively will be representing the occurrence of erosion and sedimentation. While, the direction of sediment distribution indicated by vector direction. In Figure 9 (spring period) and Figure 10 (neap period), it will shown that sediment distribution pattern represented by cumulative erosion/sedimentation and sediment distribution in the direction at Cilacap's Waters.

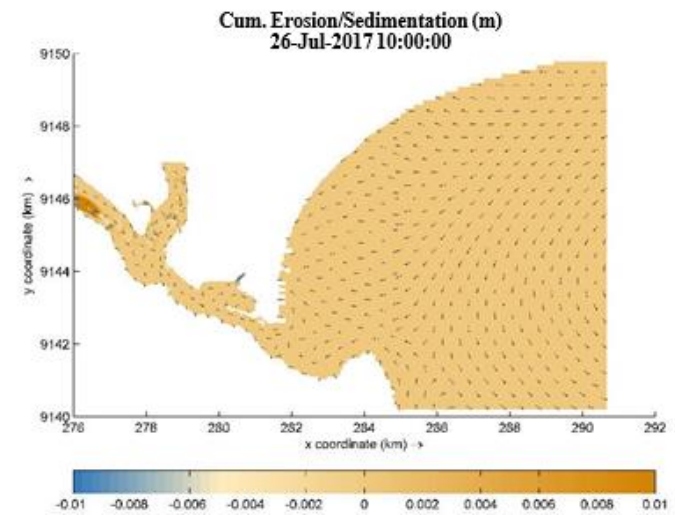

Figure 11. Patterns of Sediment Cilacap's Waters at Flood Spring Tide.

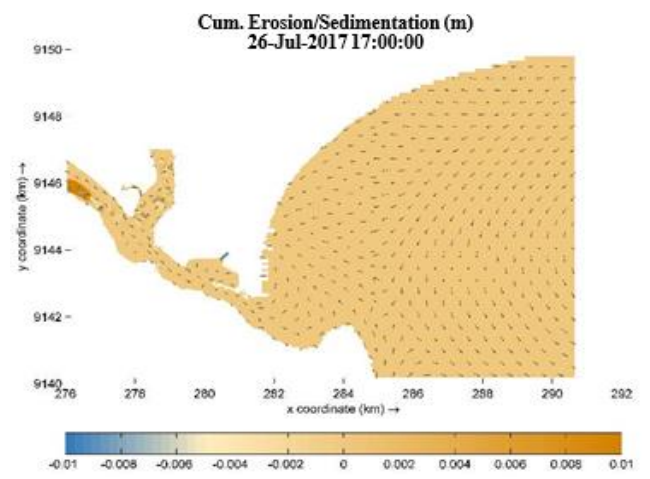

Figure 12. Patterns of Sediment Cilacap's Waters at Ebb Spring Tide.

Through cumulative erosion/sedimentation can be known that the pattern of sediments distribution in spring period, dominant occur at river and Cilacap Strait. The value erosion that occurred in the area has a thickness of sediments between 0.004 to more than 0.01 meters and value sedimentation between 0.002 up to more than 0.01 meters. On flood spring tide conditions, the movement of sediment at river mouth has direction towards to river. While ebb spring tide period, direction of sediment came from river and moving out from mouth of river.

In this neap period (Figure 13 and 14), phenomenon of erosion vicinity of river area and Strait of Cilacap has value and wide of erosion/sedimentation was greater than in the spring period. Seen that in the area, blue colour gradation to white colour getting more widespread. The value erosion in this area has a thickness between 0.005 up to more than 0.01 meters. Mean while, the thickness of sediment while experiencing sedimentation of 0.002 up to more than 0.01 meters. With motion of current during neap period have same direction with spring period. 


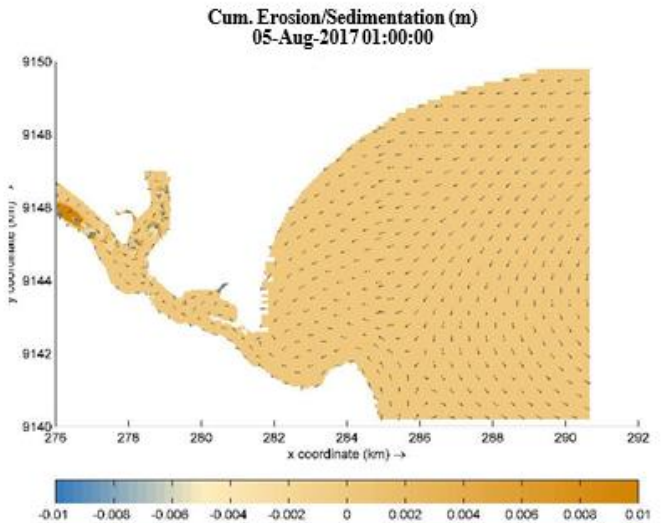

Figure 13. Patterns of Sediment Cilacap's Waters at Flood Neap Tide.

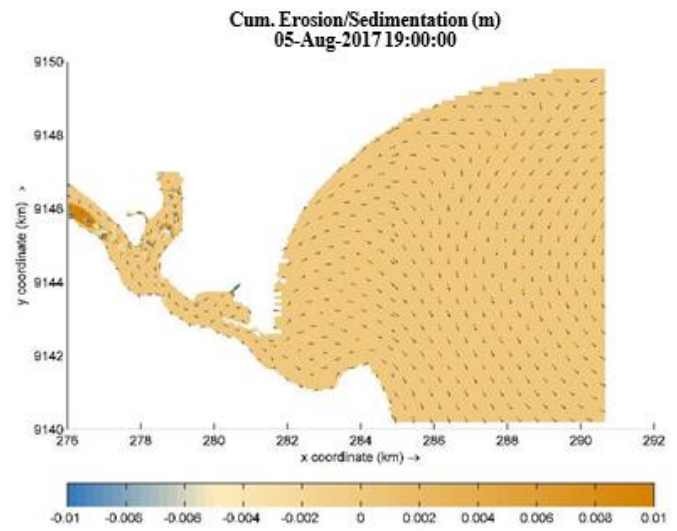

Figure 14. Patterns of Sediment Cilacap's Waters at Ebb Neap Tide.

\section{E. Evaluation Impact of Sediment Patterns on Jetty}

Based on results of the simulation in the area of jetty, resulting condition of sediment activity. Can be seen in the cumulative erosion/sedimentation as in Figure 15, give information about material movement of sediments in this region.

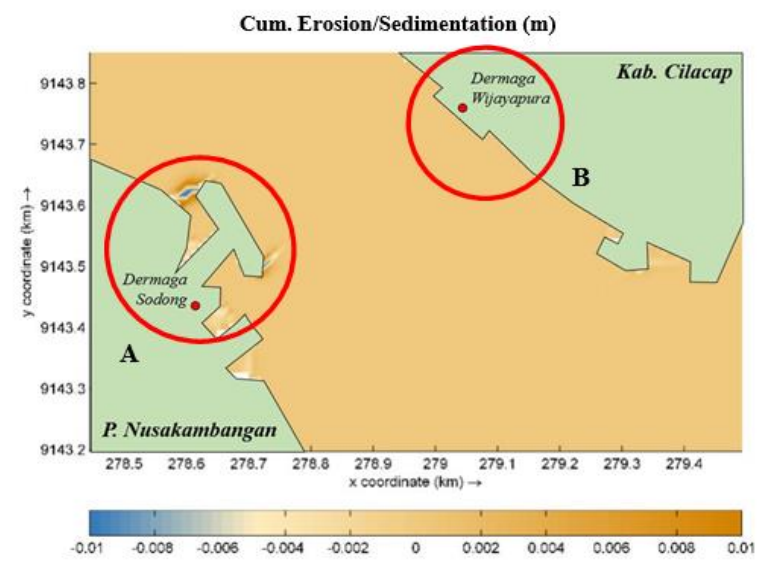

Figure 15. Cumulative Erosion/Sedimentation Around Jetty.

Location A which is the location of Sodong Jetty (Nusakambangan Island), seen at this location occurred erosion/sedimentation activity. Then on site of $\mathrm{B}$ which shows location of Wijayapura Jetty, where in this area does not experience erosion/sedimentation. Monitoring depth of change focused on area of jetty in this research, which is appointed by Figure 16 .

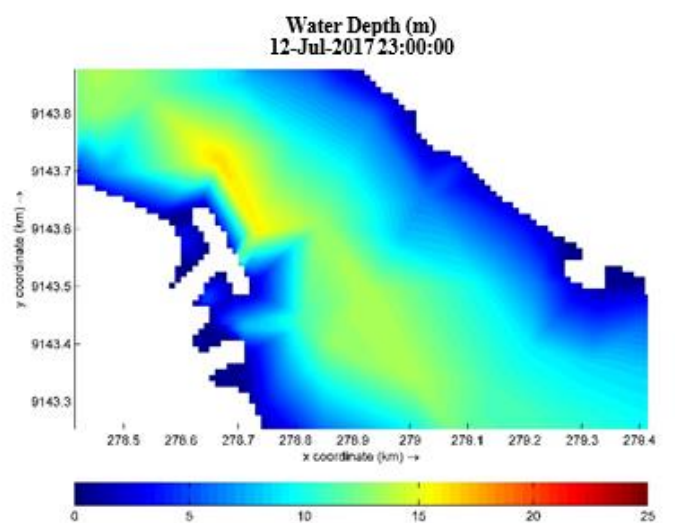

(a)

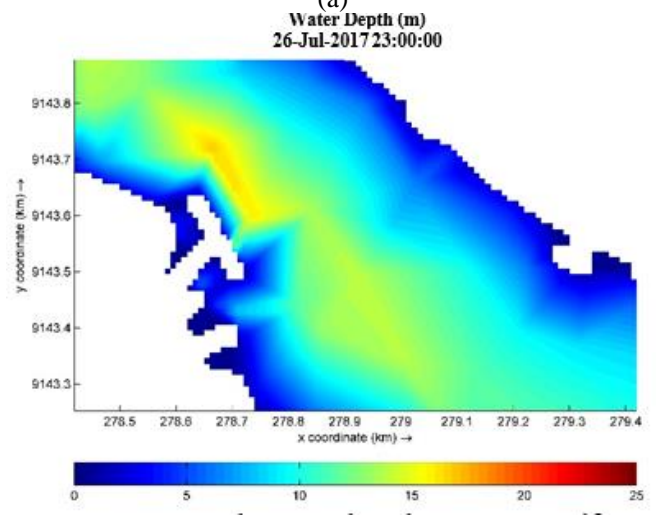

(b)

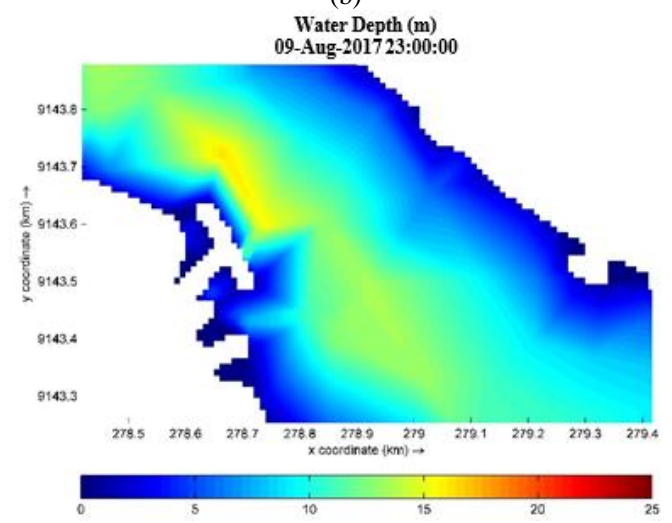

(c)

Figure 16. (a) The Depth Change at Initial Condition of Simulation Model, (b) The Depth Change at Half Condition of Simulation Model, (c) The Depth Change at Finish Condition of Simulation Model.

A third of figure has different at the time of observation in the temporal time. In Figure 14a, b and c show the depth on initial condition of simulation, half of simulation, and finish of simulation modelling. To make it easier to find out value of depth change due to activity of sediment, took observation sample randomly that it's located near with Wijayapura Jetty and Sodong Jetty. The location and depth change as in Table 4. 
TABLE 4.

THE VALUE OF DEPTH CHANGE

\begin{tabular}{|c|c|c|c|c|}
\hline \multirow[b]{2}{*}{ Jetty } & \multirow{2}{*}{$\begin{array}{c}\text { Name } \\
\text { Of } \\
\text { Point }\end{array}$} & \multicolumn{3}{|c|}{ "Depth Change (m) } \\
\hline & & Initial & Half & Finish \\
\hline \multirow[t]{9}{*}{ Sodong } & A & 0.001 & 0.002 & 0.003 \\
\hline & B & -0.149 & -0.100 & -2.316 \\
\hline & $\mathrm{C}$ & 0.211 & 0.295 & 0.698 \\
\hline & D & -4.7811 & -11.480 & -12.879 \\
\hline & E & -1.346 & -1.366 & -1.727 \\
\hline & $\mathrm{F}$ & 0.001 & 0.002 & 0.003 \\
\hline & G & 3.217 & 5.010 & 10.656 \\
\hline & $\mathrm{H}$ & 5.446 & 29.414 & 128.120 \\
\hline & I & 1.926 & 3.251 & 6.272 \\
\hline \multirow{6}{*}{ Wijayapura } & $\mathrm{J}$ & 4.585 & 10.180 & 19.818 \\
\hline & K & 0.000 & 0.000 & 0.000 \\
\hline & $\mathrm{L}$ & 0.000 & 0.000 & 0.000 \\
\hline & M & 0.000 & 0.000 & 0.000 \\
\hline & $\mathrm{N}$ & 0.000 & 0.000 & 0.000 \\
\hline & $\mathrm{O}$ & 0.000 & 0.000 & 0.000 \\
\hline
\end{tabular}

From Table 4 can be known that activity of erosion/sedimentation occur vicinity at Sodong Jetty. And activity of erosion/sedimentation does not occur in te Wijayapura Jetty. Through 10 samples point erosion/sedimentation near Sodong Jetty there is a 7 points that experience sedimentation, with maximum depth change is 128.120 millimeters within one month at sample point $\mathrm{H}$. some of sample point can be known cumulative erosion/sedimentation in each jetty as in Table 5 .

TABLE 5.

Cumulative EROSION/SEDIMENTATION

\begin{tabular}{ccc}
\hline \multicolumn{3}{c}{ CUMULATIVE EROSION/SEDIMENTATION } \\
\hline Jetty & $\begin{array}{c}\text { Cum.Erosion } \\
(\mathbf{m m} / \mathbf{b l n})\end{array}$ & $\begin{array}{c}\text { Cum. } \\
\text { Sedimentation } \\
(\mathbf{m m} / \mathbf{b l n})\end{array}$ \\
\hline Sodong & -16.921 & 165.571 \\
Wijayapura & 0.000 & 0.0000 \\
\hline \hline
\end{tabular}

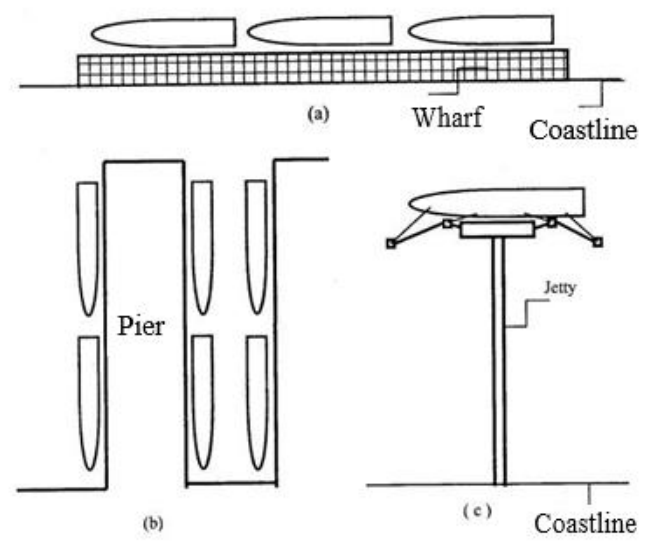

Figure 17. Different of Port Which is Divided into Three Types, namely (a) Wharf, (b) Pier, (c) Jetty.

It is known that the pattern of sediment distribution in the Cilacap's Waters given effect to existence of jetty at this waters. It can be seen that sediment distribution pattern greatly influence the morphology of sea bed vicinity Sodong Jetty, compared in the Wijayapura Jetty. On the Sodong Jetty, dominant experience sedimentation of $165.710 \mathrm{~mm} / \mathrm{month}$. The Jetty is type dock from Sodong Port, where is the jetty juts out into sea, so that it's front side at a depth sufficient to mooring ship. On the otherhand the type of Wijayapura jetty is wharf. Wharf is parallel jetty that with the coast and usually coincide with coastline [6]. Figure 17 shows type of jetty.

The difference shape and type of jetty, makes one of some factors of occurrence from erosion/sedimentation activity on both jetty. So, need monitoring and dredging sediment periodically. If this not done, can lead to disruption of shipping activity on Sodong Jetty, such as a shipwreck.

\section{CONCLUSION}

Based on the results of processing and data analysis has been done. It's known that currents velocity in the waters of Cilacap ranged from 0 up to $0.8 \mathrm{~m} / \mathrm{s}$, with the greatest velocity at flood spring period condition. In addition it's known that direction of currents is moving according period of tide and direction of current in the river is exit from mouth of river. Then, the pattern of sediment distribution on Cilacap's Waters cause erosion/sedimentation activity, with the greatest activity occurs in rivers and Cilacap Strait of 0.002 up to more than 0.01 meters. So, by looking at the current and sediment distribution in jetty given effect to Sodong Jetty, namely occurrence more shallow depth. With maximum of depth change is $128.120 \mathrm{~mm}$ and cumulative sedimentation of $165.710 \mathrm{~mm} / \mathrm{month}$ within one month that occur at Sodong Jetty. So that needs to be done monitoring and activity of sediment dredging periodically.

\section{ACKNOWLEDGMENT}

The authors give thanks to Agency for Metereology, Climatology, and Geophysics (BMKG), Geospatial Information Board (BIG), and Hydrography and Oceanography Center Indonesian Navy (Pushidrosal) who has provided data and guidance during in this research.

\section{REFERENCES}

C. Willmott and K. Matsuura, "Advantages of the mean absolute error (MAE) over the root mean square error (RMSE) in assessing average model performance," Clim. Res., vol. 30, pp. 79-82, 2005.

[2] Badan Pusat Statistik, "Kecamatan Tawangsari Dalam Angka 2017," Sukoharjo, 2017.

[3] A. Widhayanti, A. Ismanto, and B. Yulianto, "Sebaran Tumpahan Minyak dengan Pendekatan Model Hidrodinamika dan Spill Analysis di Perairan Cilacap, Jawa Tengah," J. Oceanogr., vol. 4, no. 4, pp. 641-650, Oct. 2015.

[4] Badan Pusat Statistika, "Kabupaten Cilacap Dalam Angka (2017," Cilacap, 2017.

[5] Sanidhya Nika Purnomo and Wahyu Widiyanto, "Analisis Sedimentasi di Pelabuhan Pendaratan Ikan (PPI) Logending Sedimentation Analysis at Logending Fish Landing Port."

[6] I. Hasan, Analisis Data Penelitian dengan Statistika. Jakarta: Bumi Aksara, 2009. 